\title{
Ribonucleoprotein PTB-Binding 1
}

National Cancer Institute

\section{Source}

National Cancer Institute. Ribonucleoprotein PTB-Binding 1. NCI Thesaurus. Code C131188.

Ribonucleoprotein PTB-binding 1 (606 aa, 64 kDa) is encoded by the human RAVER1 gene. This protein is involved in RNA binding and alternative splicing. 